\title{
ANALISIS BEBAN KERJA PERAWAT PELAKSANA DI RUANG RAWAT INAP DI RSU BAHTERAMAS SULAWESI TENGGARA
}

\author{
Iqra $S^{1 凶}$, Rusna Tahir ${ }^{2}$ \\ ${ }^{1}$ Jurusan Keperawatan Poltekkes Kemenkes Mamuju \\ ${ }^{2}$ Jurusan Keperawatan Poltekkes Kemenkes Kendari
}

\begin{tabular}{l}
\hline ARTICLE INFO \\
\hline Article history \\
Submitted : 2019-07-30 \\
Revised : 2020-07-22 \\
Accepted : 2020-07-27 \\
Keywords: \\
Workload \\
Nurse \\
Ward
\end{tabular}

Kata Kunci:

Beban Kerja

Perawat

Ruang Perawatan

\begin{abstract}
The quality of health services, one of which is determined by the quality of nursing services provided to patients. Workload problems felt by nurses both qualitatively and quantitatively often cause a decrease in the quality of care services that are sometimes not noticed by the hospital. This study aimed to identify the workload of nurses working in class I, class II, and class III treatment rooms. This study was an observational analytic cross-sectional study approach. The samples were 74 female nurses who worked for $\geq 2$ years in the treatment room. They were selected by purposive sampling. Data collection was done through questionnaires, observations, and interviews. Data were analyzed by Kruskal Wallis analysis to see differences in workloads between three treatment rooms. The results showed a significant difference in workload between the three treatment rooms $(\mathrm{p}=0.037)$, where class III treatment rooms had a greater workload compared to other treatment rooms (Mean rank $=45.81)$. The need for an analysis of the needs of nurses is adjusted to the level of dependence of patients in each room so that the workload received by nurses in accordance with existing conditions.
\end{abstract}

Kualitas layanan kesehatan salah satunya ditentukan oleh kualitas layanan keperawatan yang diberikan kepada pasien. Masalah beban kerja yang dirasakan oleh perawat baik secara kualitatif dan kuantitatif sering menyebabkan penurunan kualitas layanan perawatan yang kadang-kadang tidak diperhatikan oleh rumah sakit. Penelitian ini bertujuan untuk mengidentifikasi beban kerja perawat yang bekerja di ruang perawatan kelas I, kelas II, dan kelas III. Penelitian ini adalah analitik observasional dengan pendekatan cross sectional study. Sampel diambil sebanyak 74 perawat wanita yang bekerja $\geq 2$ tahun di ruang perawatan, dan sampel dipilih secara purposive sampling. Pengumpulan data dilakukan melalui kuesioner, observasi, dan wawancara. Data dianalisis dengan analisis Kruskal Wallis untuk melihat perbedaan dalam beban kerja di antara tiga ruang perawatan. Hasil penelitian menunjukkan perbedaan yang signifikan dalam beban kerja di antara ketiga ruang perawatan $(\mathrm{p}=0,037)$, di mana ruang perawatan kelas III memiliki beban kerja yang lebih besar dibandingkan dengan ruang perawatan lainnya (Mean rank $=45,81$ ). Perlunya dilakukan analisis kebutuhan tenaga perawat yang disesuaikan dengan tingkat ketergantungan pasien di ruangan masingmasing, sehingga beban kerja yang diterima perawat sesuai dengan kondisi yang ada.

$\triangle$ Corresponding Author:

Iqra $S$

Jurusan Keperawatan Poltekkes Kemenkes Mamuju

Telp. 085255532277

Email: iqra.sy@gmail.com

\section{PENDAHULUAN}

Pelayanan keperawatan merupakan salah satu cerminan mutu pelayanan kesehatan di rumah sakit secara keseluruhan. Besarnya peran perawat dalam sistem tatanan pelayanan kesehatan di rumah sakit, menyebabkan adanya tuntutan kerja tinggi yang harus ditunjukkan perawat dalam memberikan asuhan keperawatan yang berkualitas. Sehingga tidak jarang ditemukan munculnya masalah penurunan kinerja bagi perawat oleh karena burnout yang dialaminya. Burnout merupakan keadaan individu yang mengalami kelelahan, depersonalisasi, dan menurunnya kinerja akibat keterlibatan diri pada pekerjaan yang memiliki banyak tuntutan emosional dan terlalu sedikit sumber kepuasan atau adanya ketidakpuasan (Moorhead \& Griffin, 2013).

Burnout dapat memberikan dampak yang negatif terhadap penampilan kerja perawat dalam memberikan asuhan keperawatan. Selain itu, burnout juga dapat 
berdampak pada rendahnya kepuasan kerja perawat, berkurangnya komitmen terhadap organisasi, dan meningkatnya intention turnover perawat (Laschinger \& Wong, 2014).

Salah satu faktor yang menjadi penyebab munculnya burnout bagi perawat yang banyak di bicarakan saat ini adalah karena adanya beban kerja yang berlebihan pada perawat (Xanthopoulou et al., 2007). Volume kerja yang tidak sesuai dengan kemampuan diri perawat akan menyebabkan perawat bekerja lebih ekstra dalam memenuhi pelayanan keperawatan kepada pasien. Kondisi ini akan menjadi pemicu kelelahan emosional perawat dari aktivitas tersebut yang pada akhirnya berdampak pada kinerja yang ditunjukkan. Memperhatikan aspek beban kerja yang baik bagi perawat adalah hal yang penting bagi institusi pelayanan kesehatan (Whitebead et al., 2010).

Bagi perawat, selain berinteraksi dengan pasien perawat juga dihadapkan pada beban kerja lainnya seperti bekerja semaksimal dengan keterbatasan jumlah tenaga maupun jadwal dinas yang padat. Selain itu sering kali mereka dihadapkan pada kondisi-kondisi kritis pasien yang mengancam pada kematian pasien, ataupun ketidakjelasan waktu penyembuhan (Lailani, 2012). Kondisi dengan beban kerja yang berlebihan ini akan menjadi sumber tekanan kerja perawat dalam bekerja sehingga menjadi penentu kualitas kinerja pada perawat (Xanthopoulou et al., 2007).

Menurut (Marquis \& Huston, 2010) beban kerja pada konteks keperawatan merupakan seluruh kegiatan atau aktivitas yang dilakukan perawat selama bertugas di suatu unit pelayanan keperawatan. Sedangkan (Hadley et al., 2004) menjabarkan beban kerja perawat sebagai jumlah perawatan yang dilakukan terhadap pasien yang berdasarkan atas penilaian perawat pada kebutuhan keperawatan pasien tersebut, dan perawatan lain yang pasien butuhkan.

Gaudine dikutip dalam (Kurniadi, 2013) memberikan pandangan yang sedikit berbeda, dimana beban kerja dilihat dari jumlah total waktu keperawatan baik secara langsung atau tidak langsung dalam memberikan pelayanan keperawatan yang diperlukan oleh pasien dan jumlah perawat yang dibutuhkan untuk memberikan pelayanan tersebut. Segala aktivitas perawat dalam kegiatan selama bertugas merupakan beban kerja yang menjadi tanggung jawabnya, baik yang langsung kontak dengan pasien maupun tidak secara langsung. Contoh untuk waktu keperawatan berupa tindakan yang langsung kontak dengan pasien yaitu melakukan pengkajian, mengukur tanda-tanda vital, membantu personal hygiene, menemani pasien bercakap-cakap, dan lain-lain. Sedangkan waktu keperawatan tidak langsung yaitu tidak adanya kontak langsung dengan pasien misalnya, menulis dokumentasi pengkajian pasien, hasil tindakan, mengurus berkas rekam medis, dan lain-lain.

Hal-hal yang dapat mempengaruhi beban kerja perawat dapat dilihat melalui dua faktor yaitu faktor eksternal dan faktor internal. Faktor eksternal merupakan beban kerja yang dipengaruhi dari luar tubuh pekerja, di antaranya : 1) tugas-tugas yang dilakukan bersifat fisik seperti tempat kerja, ketersediaan alat dan sarana kerja, kondisi kerja, dan tugastugas yang bersifat mental seperti kompleksitas pekerjaan, tingkat kesulitan pekerjaan, dan tanggung jawab pekerjaan. 2) Organisasi kerja seperti lamanya waktu kerja, waktu istirahat, kerja bergilir, kerja malam, sistem pengupahan, model struktur organisasi, pelimpahan tugas dan wewenang. Faktor internal merupakan faktor yang berasal dari dalam diri individu itu sendiri yang meliputi jenis kelamin, umur, pendidikan, kondisi kesehatan, motivasi, persepsi, kepercayaan, keinginan, dan kepuasan.

Adapun tujuan dalam penelitian ini adalah untuk mengidentifikasi beban kerja perawat pelaksana di beberapa ruangan yang ada di Rumah Sakit Umum Bahteramas Provinsi Sulawesi Tenggara.

\section{METODE PENELITIAN}

Jenis Penelitian

Jenis penelitian ini adalah analitik observasional dengan pendekatan Cross sectional study.

\section{Lokasi dan Waktu Penelitian}

Penelitian ini berlokasi di ruang rawat inap (kelas 1, kelas 2, dan kelas 3) RSU. Bahteramas Provinsi Sultra. Penelitian dilaksanakan pada bulan Mei - Juni 2014.

\section{Populasi dan Sampel}

Populasi penelitian adalah seluruh perawat pelaksana yang bekerja di ruang rawat inap RSU. Bahteramas. Sampel terpilih sebanyak 74 orang yang dipilih secara purposive 
sampling dan telah memenuhi kriteria inklusi yaitu perawat pelaksana berjenis kelamin perempuan dan bekerja lebih dari 2 tahun.

\section{Pengumpulan Data}

Instrumen untuk mengukur beban kerja perawat berupa kuesioner yang diadopsi dari penelitian Mastini (2013) yang bersumber dari Nursalam (2003) yang telah teruji validitas dan reliabilitasnya $(\mathrm{r}$ hitung $=0,530-0,867$, dan cronbach alpha $=0,9)$. Pertanyaan terdiri dari 13 pertanyaan tentang beban kerja yang dipersepsikan perawat berdasarkan banyaknya pekerjaan yang harus dilakukan maupun tingkat kesulitan atau kerumitan pekerjaannya.

Rentang jawaban yang digunakan yaitu mulai dari tidak pernah ada keluhan dalam melaksanakan tugas (skor 1), kadang-kadang ada keluhan dalam melaksanakan tugas (skor 2), sering ada keluhan dalam melaksanakan tugas (skor 3), dan selalu timbul keluhan dalam melaksanakan tugas (skor 4). Selain itu, dilakukan pula observasi terhadap jenis pekerjaan yang dilakukan perawat untuk mengetahui beban kerja secara kuantitas.

\section{Pengolahan dan Analisis Data}

Data dianalisis berdasarkan skala ukur dan tujuan penelitian dengan menggunakan perangkat lunak program komputerisasi. Data dianalisis secara univariat untuk melihat distribusi frekuensi dari karakteristik responden dan variabel.

Sedangkan untuk memperoleh data perbedaan beban kerja berdasarkan ruangan perawat digunakan uji kruskal-wallis. Penelitian ini juga telah mendapatkan persetujuan dari Komisi Etik Penelitian Kesehatan Fakultas Kedokteran Universitas Hasanuddin dengan nomor 0933/H4.8.4.5.31/ PP36-KOMETIK/2014.

\section{HASIL PENELITIAN}

Berdasarkan tabel 1, diketahui bahwa sebagian besar umur responden lebih dari 30 tahun yakni 46 perawat $(62,2 \%)$, dan untuk lama kerja perawat sebagian besar berada antara $2-5$ tahun yaitu 31 perawat $(41,9 \%)$. Untuk kategori strata pendidikan terakhir perawat terbanyak vokasional yakni 63 perawat $(85,1 \%)$, dengan 49 perawat $(66,2 \%)$ telah menikah. Adapun untuk distribusi responden berdasarkan ruangan, responden terbanyak berada pada ruangan Mawar yaitu 28 responden $(37,8 \%)$.
Tabel 1. Distribusi Frekuensi Karakteristik Responden

\begin{tabular}{|c|c|c|c|}
\hline No & Karakteristik & $\mathrm{n}$ & $\%$ \\
\hline 1 & $\begin{array}{l}\text { Umur Responden } \\
\leq 30 \text { tahun } \\
>30 \text { tahun }\end{array}$ & $\begin{array}{l}28 \\
46\end{array}$ & $\begin{array}{l}37,84 \\
62,16\end{array}$ \\
\hline 2 & $\begin{array}{l}\text { Lama Kerja } \\
\qquad 2-5 \text { tahun } \\
6-9 \text { tahun } \\
\geq 10 \text { tahun }\end{array}$ & $\begin{array}{l}31 \\
23 \\
20\end{array}$ & $\begin{array}{l}41,89 \\
31,08 \\
27,03\end{array}$ \\
\hline 3 & $\begin{array}{l}\text { Pendidikan } \\
\text { Vokasional } \\
\text { Profesional }\end{array}$ & $\begin{array}{l}63 \\
11\end{array}$ & $\begin{array}{l}85,14 \\
14,86\end{array}$ \\
\hline 4 & $\begin{array}{l}\text { Status Pernikahan } \\
\text { Belum menikah } \\
\text { Menikah }\end{array}$ & $\begin{array}{l}25 \\
49\end{array}$ & $\begin{array}{l}33,78 \\
66,22\end{array}$ \\
\hline 5 & $\begin{array}{l}\text { Unit Kerja } \\
\text { Kelas I } \\
\text { Kelas II } \\
\text { Kelas III }\end{array}$ & $\begin{array}{l}22 \\
28 \\
24\end{array}$ & $\begin{array}{l}29,73 \\
37,84 \\
32,43\end{array}$ \\
\hline
\end{tabular}

Hasil analisis pada variabel beban kerja dapat dilihat pada tabel di bawah ini :

Tabel 2. Beban Kerja pada Perawat Pelaksana di Ruang Rawat Inap

\begin{tabular}{|c|c|c|}
\hline Beban Kerja & $\mathrm{n}$ & $\%$ \\
\hline Optimal & 47 & 63,5 \\
\hline Berat & 27 & 36,5 \\
\hline Total & 74 & 100 \\
\hline
\end{tabular}

Berdasarkan tabel 2 diketahui bahwa beban kerja perawat secara kualitatif terbanyak berada pada kategori optimal.

Tabel 3 menunjukkan bahwa pada ruangan kelas I beban kerja terbanyak berada pada kategori optimal dan pada kelas II terbanyak pada kategori optimal, sedangkan pada ruangan kelas III terdistribusi sama pada kategori optimal dan berat. Dari hasil analisis diketahui bahwa terdapat perbedaan beban kerja perawat berdasarkan ruangan perawatan $(p=0,037)$ dimana ruangan kelas III memiliki beban kerja yang paling tinggi dibandingkan ruangan lainnya.

\section{PEMBAHASAN}

Berdasarkan hasil penelitian ditemukan bahwa secara umum beban kerja perawat di ruang perawatan terbanyak berada pada kategori optimal yaitu sebanyak $63,5 \%$ 
sedangkan beban kerja kategori berat sebanyak $36,5 \%$. Beban kerja yang dirasakan perawat merupakan respon subjektif terhadap akumulasi dari penggunaan waktu perawat selama bertugas dalam memberikan asuhan keperawatan sesuai dengan kebutuhan pasien (Kurniadi, 2013). Sehingga beban kerja perawat dapat dilihat dari banyaknya kegiatan yang dilakukan perawat terkait perawatan langsung maupun tidak langsung kepada pasien, yang mana kegiatan ini akan menjadi beban kerja yang dirasakan perawat sesuai atau tidak dengan kemampuan dirinya.

Tabel 3. Perbedaan Beban Kerja pada Perawat Berdasarkan Ruangan

\begin{tabular}{|c|c|c|c|c|c|c|c|c|}
\hline \multirow{3}{*}{$\begin{array}{c}\text { Ruang Kelas } \\
\text { Perawatan }\end{array}$} & \multicolumn{4}{|c|}{ Beban Kerja } & \multirow{2}{*}{\multicolumn{2}{|c|}{ Jumlah }} & \multirow{3}{*}{$\begin{array}{l}\text { Mean } \\
\text { Rank }\end{array}$} & \multirow{3}{*}{$p$} \\
\hline & \multicolumn{2}{|c|}{ Optimal } & \multicolumn{2}{|c|}{ Berat } & & & & \\
\hline & $\mathbf{n}$ & $\%$ & n & $\%$ & n & $\%$ & & \\
\hline Kelas I & 14 & 63.64 & 8 & 36.36 & 22 & 100 & 37.36 & \\
\hline Kelas II & 21 & 75.00 & 7 & 25.00 & 28 & 100 & 30.48 & 0.037 \\
\hline Kelas III & 12 & 50.00 & 12 & 50.00 & 24 & 100 & 45.81 & \\
\hline
\end{tabular}

Rodahl mengemukakan bahwa optimalnya beban kerja yang dirasakan perawat tersebut dapat disebabkan oleh dua hal yaitu pengaruh faktor eksternal maupun internal pada diri individu perawat (Agustini, 2013). Pada faktor internal, perawat memandang bahwa pekerjaan sebagai seorang perawat merupakan suatu tugas mulia. Sehingga ada kepuasan, kepercayaan, keinginan, dan motivasi yang kuat bagi individu ketika bekerja. Hal ini menjadi faktor yang sangat kuat, dan sangat mempengaruhi individu dalam bekerja.

Hasil pengolahan data yang dilakukan ditemukan bahwa faktor internal cukup menonjol pada diri perawat yang bekerja di ruang perawatan. Gambaran kecilnya terlihat pada 8 perawat $(29,6 \%)$ yang memiliki beban kerja berat ternyata menunjukkan kinerja yang sangat baik. Peneliti mencoba mengkaji dengan melakukan wawancara pada 3 orang perawat perwakilan masing-masing ruangan yang memiliki pernyataan yang sama. Dari hasil wawancara diketahui bahwa menurut mereka melaksanakan tugas dalam memberikan pelayanan keperawatan yang terbaik adalah yang utama, sehingga sudah menjadi tanggung jawab mereka untuk bekerja semaksimal mungkin walaupun dengan beban kerja yang tinggi. Hasil yang diperoleh ini sejalan dengan penelitian (Sitepu, 2013) yang menemukan bahwa beban kerja tidak menjadi penghalang bagi individu dalam bekerja karena di dorong oleh faktor motivasi.

Hal ini sesuai dengan penjelasan (Potter \& Perry, 2010) bahwa keperawatan adalah profesi yang memberikan pelayanan dengan penuh kasih sayang, perhatian, tanggung jawab, dan rasa hormat kepada siapa pun yang dirawat. Sehingga untuk dapat melaksanakan hal ini, harus didasarkan panggilan jiwa. Oleh karena itu, pada kelompok ini menunjukkan fokus utama pelayanan perawat adalah pemenuhan kebutuhan pasien.

Selain itu, beban kerja dapat pula dipengaruhi dari kemampuan individu perawat itu sendiri seperti pengetahuan dan keterampilan yang dimiliki perawat dalam melaksanakan pekerjaan sehingga mampu dan dengan mudah menyelesaikan tugasnya. Adanya tuntutan keluarga pasien, harapan pimpinan akan kualitas pelayanan, kurangnya tenaga dan variasi pekerjaan yang terlalu banyak juga turut menambah beban kerja pada perawat (Marquis \& Huston, 2010). Asumsi ini dibuktikan dari distribusi responden, didapatkan bahwa rata-rata perawat telah berpendidikan minimal diploma keperawatan dan tidak ada lagi dengan tamatan SPK. Sehingga kemampuan yang ditunjang pengetahuan yang baik dapat menjadi penunjang optimalnya beban kerja perawat.

Pada faktor eksternal, beban kerja optimal di RSU Bahteramas telah terkelola dengan baik. Hal ini dibuktikan dengan pengaturan lamanya waktu kerja sesuai dengan standar kebijakan, waktu istirahat, kerja bergilir di antara perawat, pengaturan kerja malam, sistem pengupahan, model struktur organisasi yang telah mengikuti MPKP, serta pelimpahan tugas dan wewenang yang baik. Keseluruhan komponen ini akan menimbulkan iklim kerja yang baik sehingga individu merasa betah untuk melakukan pekerjaan walaupun telah melebihi beban kerjanya. Hasil ini sejalan 
dengan penelitian (Lestya et al., 2016) yang mengemukakan bahwa iklim kerja yang baik berkorelasi secara positif dengan beban kerja fisik karyawan.

Pada awalnya, beban kerja tersebut menjadi sebuah tantangan bagi individu untuk tetap berupaya melaksanakan pekerjaan sehingga mencapai hasil yang maksimal sesuai dengan yang diharapkannya, akan tetapi berlangsungnya secara terus menerus kondisi beban kerja yang terus meningkat dapat mengakibatkan perawat akan mencapai kemampuan maksimal pada diri sehingga menyebabkan munculnya kelelahan secara fisik maupun emosional terhadap pekerjaan itu sendiri (Laschinger \& Wong, 2014).

Berdasarkan analisis perbedaan beban kerja di antara ketiga ruang perawatan yaitu kelas I, kelas II, dan kelas III ditemukan bahwa ruangan kelas III memiliki beban kerja lebih besar dengan mean rank sebesar 45,81, dan perbedaan di antara ketiga ruangan tersebut sangat bermakna dengan nilai $p=0,037$. Dari hasil ini maka dapat disimpulkan bahwa ruang perawatan kelas III memiliki beban kerja yang lebih tinggi dibandingkan dengan ruang perawatan lainnya.

Ruangan perawatan kelas III merupakan ruang perawatan yang diberikan pada kelompok masyarakat ekonomi menengah ke bawah dengan fasilitas yang ditawarkan berupa ruang inap berkapasitas $4-6$ orang. Lebih murah dan terjangkaunya biaya dalam perawatan kelas III ditengarai menjadi penyebab jumlah pasien yang dirawat lebih banyak dengan intensitas pemanfaatan tempat tidur juga tinggi.

Tingginya beban kerja yang dipersepsikan perawat diruang perawatan kelas III dibandingkan dengan ruang perawatan lainnya sejalan dengan observasi beban kerja yang dilakukan peneliti dengan menggunakan pendekatan work sampling untuk mengamati pola kegiatan perawat dalam memberikan asuhan keperawatan baik secara langsung maupun tidak langsung. Dari 4 perawat yang diamati di ruangan kelas III, terdapat 3 perawat yang memiliki waktu kerja produktifnya $>80 \%$ dari waktu dinas. Sehingga dapat disimpulkan bahwa beban kerja dari perawat tersebut melebihi beban kerja yang seharusnya dilakukan.

Selain itu, untuk melihat pola beban kerja di ruangan masing-masing, peneliti melakukan analisis kebutuhan tenaga perawat yang didasarkan pada perhitungan Gillies sehingga didapatkan data kesesuaian jumlah tenaga yang dibutuhkan saat ini. Berdasarkan data bed ocupation rate (BOR) dan rata-rata tingkat ketergantungan pasien, diketahui bahwa kebutuhan tenaga perawat di ruangan kelas I yaitu 25 perawat (saat ini 31 perawat), di ruangan kelas II yaitu 20 perawat (saat ini 31 perawat), dan di ruangan kelas III yaitu 36 perawat (saat ini 30 perawat). Dari hasil perhitungan ini menunjukkan adanya ketidaksesuaian kebutuhan tenaga pada ruangan kelas III yang masih kurang 6 perawat, sedangkan di ruangan kelas I dan kelas II berlebih dari kebutuhan yang seharusnya.

Tidak sesuainya rasio jumlah perawat dengan jumlah pasien akan semakin menambah beban kerja perawat di ruangan tersebut. Hal ini senada dengan penjelasan (Nursalam, 2011) dimana beban kerja berlebih pada perawat sering kali disebabkan karena rasio tenaga perawat dengan pasien yang tidak seimbang, sehingga perawat mengerjakan terlalu banyak pekerjaan. Dari kondisi ini dapat menjadi pemicu munculnya kelelahan emosional bagi perawat di ruangan kelas III yang dapat berdampak pada kinerjanya. Seperti hasil penelitian (Shirom et al., 2010) maupun (Tamaela, 2011) yang menemukan bahwa beban kerja merupakan variabel yang memiliki hubungan searah dengan tingginya burnout sehingga dapat menyebabkan penurunan kinerja.

Dari wawancara yang dilakukan pada kepala ruangan di tiga ruangan, ditemukan adanya beberapa kegiatan tambahan yang dapat menambah beban kerja perawat di antaranya mengikuti apel pagi pada jam 07.15 untuk perawat jaga pagi, harus mengantar pasien ke ruangan radiologi maupun poliklinik, dan mengurus administrasi pasien. Menurut kepala ruangan, adanya pekerjaan tambahan ini menyebabkan semakin banyaknya kesibukan perawat sehingga interaksi yang digunakan dalam memberikan asuhan keperawatan dengan pasien berkurang. Selain itu, pada observasi ditemukan pula adanya waktu kerja yang terlalu banyak digunakan perawat dalam pendokumentasian asuhan keperawatan $( \pm 25 \%$ dari waktu kerja), dan bahkan beberapa perawat mengeluhkan pendokumentasian ini terlalu banyak sehingga muncul rasa malas untuk melengkapi pendokumentasian. Banyaknya 
variasi kerja yang di kerjakan perawat inilah yang akan semakin menambah beban kerja yang dipersepsikannya (Sadock \& Sadock, 2010).

Demikian pula pernyataan dari perawat mengenai beban kerja ditemukan adanya beberapa keluhan yang menambah beban kerja perawat. Di antaranya pada pertanyaan beban kerja terhadap kontak langsung perawat dengan pasien ditemukan ada $54,2 \%$ perawat di ruangan kelas III merasa sering menjadi beban dalam melaksanakan tugas. Dari observasi yang dilakukan peneliti di ruangan kelas III, diketahui bahwa pasien yang dilayani adalah masyarakat yang pada umumnya tidak mampu. Menurut salah salah satu perawat di ruangan kelas III, bahwa beratnya beban kerja yang dirasakan selama memberikan pelayanan adalah pasien di kelas III memiliki kecenderungan untuk susah diatur, contohnya keluarga pasien yang terlalu banyak menjaga pasien di ruangan sehingga sering mengganggu kenyamanan perawat untuk bekerja. Selain itu, ditinjau dari karakteristik penyakit pasien yang dirawat sering juga berkaitan dengan penyakit-penyakit menular seperti TBC, hepatitis, dan lain-lain. Salah satu contoh adanya isu virus MERS (Midlle east respiratory syndrome) pada beberapa pasien, perawatannya dilakukan di ruangan kelas III ini sehingga terkadang menjadikan perawat merasa cemas dalam memberikan pelayanan keperawatan. Hal-hal inilah yang memungkinkan dapat menambah beban kerja yang dipersepsikan perawat di ruangan kelas III.

Jika dilihat dari standar beban kerja berdasarkan waktu jam kerja yang ditentukan rumah sakit pada umumnya sudah sesuai. Dimana setiap perawat wajib bekerja selama 42 jam per minggu, sehingga pengaturan jadwal dinas perawat yang telah dilakukan kepala ruangan sesuai dengan porsi masing-masing perawat setiap minggunya. Akan tetapi jika dilihat dari distribusi jadwal jaga berdasarkan 3 shift di ruangan kelas III ditemukan adanya hal yang tidak sesuai. Dimana perawat jaga pagi rata-rata 15 perawat, jaga sore dan malam masing-masing 5 perawat. Jika dilihat dari perhitungan distribusi perawat berdasarkan shift dengan metode Gillies, seharusnya di ruangan kelas III ini pada jaga sore sebanyak 11 perawat. Sehingga banyak ditemukan perawat yang mengeluh merasakan sangat sibuk dan melelahkan pada saat dinas sore.
Berbeda halnya dengan beban kerja perawat di ruangan kelas I yang pada umunya terbanyak berada pada kategori optimal yaitu 14 perawat $(63,6 \%)$, dan hanya 9 perawat $(36,4 \%)$ yang beranggapan berat. Akan tetapi dari beberapa pertanyaan tentang beban kerja pada perawat di kelas I, ditemukan adanya pertanyaan-pertanyaan yang direspons menjadi beban bagi perawat dalam bekerja di antaranya adalah beban karena tuntutan keluarga akan kesehatan pasien ditemukan $72,7 \%$ perawat merasa sering menjadi beban, dan ada 54,5\% perawat kadang merasa pengetahuan dan keterampilannya tidak mampu mengimbangi kesulitan dalam pekerjaan. Selain itu, beban kerja oleh karena harapan pimpinan akan pelayanan yang berkualitas ditemukan sebanyak $45,5 \%$ perawat menjawab sering menjadi beban. Hal ini menunjukkan adanya perbedaan beban kerja yang dipersepsikan perawat yang semakin meningkatkan yang dialami perawat dikelas I dibandingkan dengan ruangan kelas III. Dimana pada ruangan kelas III beban kerja lebih dikarenakan kurangnya jumlah tenaga dan kontak dengan pasien yang berisiko menular cukup tinggi.

Pada ruangan perawatan kelas II merupakan ruangan yang memiliki nilai beban kerja paling rendah dibandingkan dengan dua ruangan lainnya. Jika ditinjau dari beban kerja selama observasi dari 4 perawat memang waktu kerja produktifnya rata-rata $<80 \%$ jam kerja, begitu pula dari data BOR selama bulan Mei hanya mencapai $56,6 \%$ dengan kata lain tidak mencapai standar BOR ideal yaitu 70-80\%. Sehingga ruangan kelas II ini memiliki beban kerja yang cukup baik dan sesuai dengan jumlah perawat.

\section{KESIMPULAN DAN SARAN}

Dari hasil penelitian ini dapat disimpulkan bahwa terdapat perbedaan yang bermakna beban kerja di antara ruang perawatan kelas I, kelas II, dan kelas III. Sedangkan ruang perawatan kelas III memiliki beban kerja yang lebih besar dibandingkan dengan ruang perawatan lainnya.

Penelitian ini merekomendasikan perlunya dilakukan analisis kebutuhan tenaga perawat yang disesuaikan dengan tingkat ketergantungan pasien di ruangan masingmasing, sehingga beban kerja yang diterima perawat sesuai dengan kondisi yang ada. Selain itu, perlunya perbaikan pada sistem pengelolaan 
dokumentasi asuhan keperawatan (askep) yang lebih efektif untuk mengurangi waktu kerja perawat dalam mendokumentasikan askep contohnya menggunakan format check list, dan pengadaan tenaga administrasi maupun evakuator untuk mengurangi variasi kerja perawat, sehingga kegiatan perawat dapat lebih berfokus pada pemenuhan kebutuhan pasien. Penerapan model cheklist dalam pendokumentasian asuhan keperawatan lebih memudahkan perawat dalam mendokumentasikan serta waktu yang digunakan lebih efisien.

\section{DAFTAR PUSTAKA}

Agustini, T. (2013). Analisis beban kerja perawat pelaksana berdasarkan karakteristik, jenis ruang perawatan, dan pengaturan shift di ruang rawat inap Rumah Sakit Ibnu Sina YW-UMI Makassar tahun 2013. Universitas Hasanuddin.

Hadley, F., Graham, K., \& Flannery, M. (2004). Workforce management objective a: Assess use, compliance and efficacy nursing workload measurement tools. March 2004, 1-97.

Kurniadi, A. (2013). Manajemen keperawatan dan prospektifnya: Teori, konsep, dan aplikasi. Badan Penerbit: Fakultas Kedokteran Universitas Indonesia.

Lailani, F. (2012). Burnout Pada Perawat Ditinjau Dari Efikasi Diri dan Dukungan Sosial. Talenta Psikologi, 1(1), 66-86. https://doi.org/10.2143/TVG.69.08.2001 380

Laschinger, \& Wong. (2014). Resonant Leadership and Workplace Empowerment: Nursing Economic\$, 32(1), 5-16.

Lestya, D. N. W., Rachman, F., \& Wiediartini. (2016). Anaslisis Faktor Eksternal dan Internal Yang Mempengaruhi Beban Kerja Fisik Pada pekerjaan Finisshing Di Perusahaan Fabrikasi Baja. Conference on Safety Engineering and Its Application, 2581, 24-28.

Marquis, B. L., \& Huston, C. J. (2010). Kepemimpinan dan manajemen keperawatan: Teori \& aplikasi (4th ed.). EGC.

Moorhead, G., \& Griffin, R. W. (2013). Perilaku Organisasi: Manajemen sumber daya manusia dan organisasi (Diana Anggelika, Trans.). Salemba Medika.

Nursalam. (2011). Manajemen keperawatan: aplikasi dalam praktik keperawatan profesional (3rd ed.). Salemba Medika.

Potter, P. A., \& Perry, A. G. (2010). Fundamental Keperawatan, edisi 7 (Adriana Frederika, Trans.) (7th ed.). Salemba Medika.

Sadock, B. J., \& Sadock, V. A. (2010). Buku Ajar Psikiatri Klinis (2nd ed.). EGC.

Shirom, A., Nirel, N., \& Vinokur, A. D. (2010). Work hours and caseload as predictors of physician burnout: The Mediating Effects by Perceived Workload and by Autonomy. Applied Psychology, 59(4), 539-565. https://doi.org/10.1111/j.14640597.2009.00411.x

Sitepu, A. (2013). Beban Kerja Dan Motivasi Pengaruhnya Terhadap Kinerja Karyawan Pada Pt. Bank Tabungan Negara Tbk Cabang Manado. Jurnal Riset Ekonomi, Manajemen, Bisnis Dan Akuntansi, 1(4), 1123-1133. https://doi.org/10.35794/emba.v1i4.2871

Tamaela, E. Y. (2011). Konsekuensi Konflik Peran, Kelebihan Beban Kerja dan Motivasi Intrinsik terhadap Burnout pada Dosen yang. 13(2), 111-122.

Whitebead, D. K., Weiss, S. A., \& Tappen, R. M. (2010). Essentials of nursing leadership and management (5th ed.). F.A Davis Company.

Xanthopoulou, D., Bakker, A. B., Dollard, M. F., Demerouti, E., Schaufeli, W. B., Taris, T. W., \& Schreurs, P. J. G. (2007). When do job demands particularly predict burnout? The moderating role of job resources. Journal of Managerial Psychology, 22(8), 766-786. https://doi.org/10.1108/02683940710837 714. 